\title{
Ownership Structure, Tax Avoidance and Firm Performance
}

\author{
Vince Ratnawati \\ Faculty of economic and business - Universitas Riau \\ Desmond Freddy \\ Hardi \\ Faculty of economic and business - Universitas Riau
}

\begin{abstract}
ABSTARCT
The aims of this study was to obtain empirical evidence of how ownership structure ie institutional and managerial ownership affect firm performance. The study also examine the moderating role of tax avoidance on the effect of institutional and managerial ownerships on firm performance. A model was developed and tested using sample of 58 manufactured companies from 2012 to 2014, which is listed on Indonesian Stock Exchange. Data were collected and analyzed using least square regression and moderated regression analisys. The result showed that institutional ownership and managerial oenrrship affect firm performance. This study also showed that tax avoidance moderates the effect of both institutional and managerial ownership on firm performance.
\end{abstract}

Keywords: Institutional Ownership, managerial ownership, tax avoidance, firm performance

\section{INTRODUCTION}

Firm performance of the company is very important, and the higher firm performance, the higher the credibility of the company. According to Wahyudi and Parwestri (2006) firm performance also describes the welfare of the owner. Allen and and Philips (2000) described that financial performance will impact on increasing share purchase by outside block ownership. This condition will cause management will attemted to do various efforts so that have the impact on increasing the firm performance. Corporate governance mechanism is a tool that can help the principal to increase the firm performance. It is caused by it can control agency cost, and therefore it will impact on increasing the firm performance. Jensen and Meckling (1976) found that institutional ownership can reduce agency conflict problems. Another finding found that institutional ownership affect the firm performance based on their controls (Nuraina, 2012). The other ownership structure ie managerial ownership can also affect the firm performance. It is because the ownership that he has will cause him to more concerned with the credibility of the company. Furthermore it has an impact to the increasing of company's performance. According Saifudin and Yuanda (2016) tax avoidance at manufacturing companies listed on the Stock Exchange period 2011-2014, increasing every year. In 2012, the average ETR arise from 0.240 to 0.260 , or an increase of 0.02 units from the previous year. Furthermore, this increase also occurs in the following year. Ie in 2013 to 0,270 and in 2014 also increased to 0.271 . This condition becomes one of the indications that the tax avoidance phenomenon from year to year has increased

\section{LITERATURE REVIEW}

Gideon (2005) found that fhe percentage of shares owned by the institution may affect the process of preparing the financial statements, thus it caused no possibility of accrualization by management, thus it may increase the firm performance. Institutional investors are generally sophisticated, and these conditions may affect the increasing of company's performance. 
Previous study was conduct by Herawati (2008), Nuraina (2012), Wida and Suartana (2014) also found that institutional ownership affects the firm's performance. This findings indicate that high institutional ownership will have an impact on firm's performance. Managerial ownership structure also affect firm performance.

The study which conduct by Siallagan and Machfoedz (2006) found that greater managerial ownership tend to improve the firm's performance. The study of Kamardin (2014) also found the effect of managerial ownership on firm performance which is proxied with ROA. Contrary, Benson and Davinson (2008) found a negative relationship between managerial ownership and firm value. High managerial ownership is perceived as giving opportunistic behavior of managers. This will cause the market to react negatively, which will have an impact on the decline company's value. It indicates that managerial ownership has a negative effect on firm performance.

Tax avoidance is an avoidance effort in paying taxes conducted by taxpayers legally and not contrary to the provisions of taxation, using methods and techniques that tend to take advantage of the weaknesses contained in the laws and regulations of taxation itself, so that the amount of taxes that payable to decrease (Pohan, 2015). Santa \& Regende (2016) found that tax avoidance are negatively effect on firm value. While Chen,Xudong, Na Hu, Xue Wang,Xiaofei Tang (2014) found that tax avoidance behavior increases agency costs and reduces firm value. However chen et al (2016) found significant positive indirect relationships between tax avoidance and market value

As discussed earlier, both institutional and managerial ownership affect firm performance, i.e. the greater the institutional and managerial ownership, the higher the firm value. Aina (2016) found that the occurrence of tax avoidance will affect the decrease in firm value.

H1: Institutional ownership affects firm value

H2: Managerial ownership affects firm value

H3: Tax avoidance moderates the effect of institutional ownership on firm value

H4: Tax avoidance moderates the effect of managerial ownership on firm value

\section{Population and Sample}

\section{DATA AND METHODOLOGY}

The population of the study is all manufacture listed companies on the Indonesian Stock Exchange between 2012- 2014. From all of manufacture companies listed on the Indonesian stock exchange from 2012 to 2014, a total of 66 companies as a sample. After, screening based on criteria depicted below in Table, 3.3, the finally sample size was 115 company. Below as shown in Table 3.1 are the detail of sample description.

Table 3.1: Sample Description

Manufacture ccompanies listed 2012-2014 


\section{Measurement of Firm Value}

Firm Value is measured by using Tobin's Q (james Tobin,1969) which is developed by Klapper and Love (Khomsiyah, 2005); and used by Chen et al (2013), Sudianto and Puspitasari (2010).

Where:

$$
\text { Tobin's } Q=: \frac{\text { MVE+DEBT }}{\text { TA }}
$$

MVE = The closing price at the end of the book $\mathrm{x}$ the number of shares outstanding

DEBT $=$ Current Liabilities + Long Term Liabilities

TA $=$ Total asset

\section{Measurement of independent variables}

Institutional ownership $=\%$ institutional ownership in the company (Siregar \& Utama, 2008; Ratnawati \& Ali, 2015)

Managerial ownership $=\%$ of managerial ownershio in the company

Tax Avoidance = Cash Effective Tax Rates (Cash_ETR) which developed by Dyreng et al. (2008).

$$
\text { Cash_ETR }=\frac{\Sigma \text { CashTaxPaid }}{\text { EPretaxIncome }} \times 100 \%
$$

\section{Techniques of data Analysis}

The test of hypotheses was done using multiple regression models as stated below:

$$
\text { Hypothesis } 1 \text { and } 2: \mathrm{FV}=\alpha+\beta 1 \mathrm{InsOwn}+\beta 2 \mathrm{MgrOwn}+\varepsilon
$$

Where

$$
\text { Hypothesis } 3 \text { and 4: FV }=\alpha+\beta 1 \text { InsOwn*TaxAv }+\beta 2 M g r O w n * M g r T a x A v ~+\varepsilon
$$

\section{$\mathrm{FV}=$ Firm Value}

InstOwn = Institutional ownership

MgrOwn = Managerial Ownership

$\mathrm{TAv}=\mathrm{Tax}$ Avoidance

Normality Testing: Using normal probability plot analysis it detected that all of the data have a normal distribution.

Multicollinearity Testing: Based on the VIF value, it can be concluded that there is no autocorrelation occure in this study. Variance Inflation Factor (VIF) value of each independent variable as shown in the following Table 3.4.1.

Table 3.4.1 Regression Result

\begin{tabular}{lcll}
\hline Model & Collinearity Statistics Tolerance & VIF & P Value \\
InstOwn & 1.000 & 1.000 & 0.017 \\
MgrOwn & 1.000 & 1.000 & 0.027 \\
InsOwnTAv & 0.921 & 1.086 & 0.041 \\
MgrOwnTAv & 0.921 & 1.086 & 0.016 \\
\hline
\end{tabular}

Dependen Variable: Firm Value (Y)

Table 3.4.1 shows that all the independent variables have a tolerance value $>0.10$ and VIF $<10$. Therefore, it can be concluded that the independent variables used in the regression model of this research is free from the problem of multicollinearity (Gozali, 2013). 
The test result showed there is no autocorrelation occurred in the regression model of this study. It can be seen from the DW value as shown in Table 3.2 below. The Durbin-Watson value of 1.761 which is the value between -2 to +2 (Gozali, 2013).

Table 3.4.2 Model summary

\begin{tabular}{|c|c|c|c|c|c|}
\hline$\overline{\text { Model }}$ & $\mathrm{R}$ & R Square & Adj R Square & F Change & Durbin Watsor \\
\hline 1 & $0.27^{a}$ & 0.077 & 0.061 & 4.996 & 1.916 \\
\hline
\end{tabular}

\section{Heteroscedasticity Testing}

The results are shown that the points on the image does not form a specific pattern and the data spread above and below the number 0 on the $Y$ axis, where this indicates that the model did not experience heterocedasticity, and this model fit for use in this study.

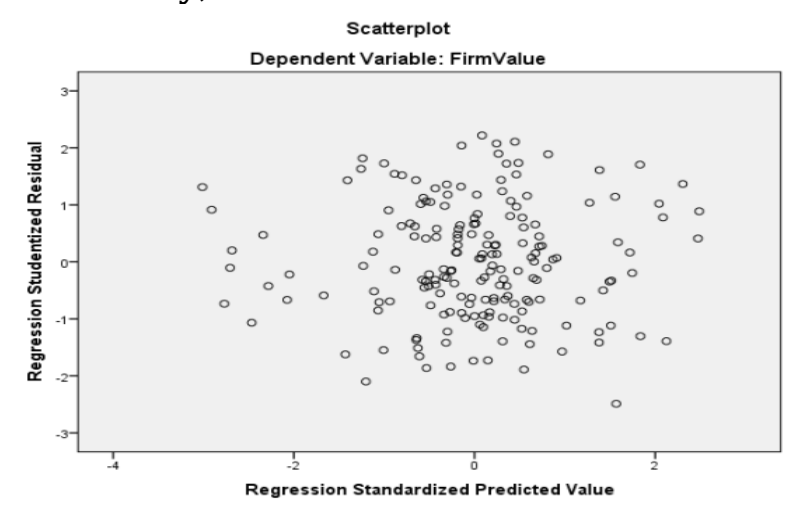

\section{RESULT AND ANALYSIS}

\section{Institutional Ownership, Managerial Ownership, and Firm Value}

From table 3.4.1 it can be seen that $\mathrm{P}$ value of institutional ownership and managerial ownership respectively have positive value 0.026 and 0.003 , which is smaller than 0.05 , so it can be concluded that both institutional ownership and managerial ownership affect firm value. Based on that finding it can be concluded that the higher the institutional ownership and managerial ownership it will be the higher the firm value. That finding indicated that institutional ownership and managerial ownership have the ability to affec the firm value. Such control is carried out through effective monitoring so that it will impact on the increased the company's credibility. These conditions will of course affect the increase in firm value. This finding is in line with Dechow et al. (1996), who found that high institutional ownership would be followed by increasing the credibility of the company's financial statements.

Gideon (2005) also found that certain percentage of shares owned by the institution could affect the process of preparing financial statements, which does not rule out any accrualization in the interest of the management. Because in general institutional investors are sophisticated investors, it will lead to institutional investors better able to utilize the current period information to predict future earnings, compared to investors other than institutional investors. This finding is also in line with Herawati (2008), Nuraina (2012), Wida and Suartana (2014). These findings indicate that high institutional ownership will impact on increasing firm value. Other findings by McConnell and Servaes (1990), Nesbitt (1994), Smith (1996), Del Guercio and Hawkins (1999), and Hartzell and Starks (2003) in Cornett et al. (2008) found empirical evidence that controls by institutional investors may limit the manager's dysfunctional behavior, which results in a decrease in firm value. Meanwhile Cornet et al. (2008) suggests that the control of the firm by an institutional investor can encourage managers to focus more attention on the company's performance so that it will reduce opportunistic or self-serving behavior, which will ultimately have an impact on the improvement of firm value. 
Managerial ownership is the ownership of shares owned by managers at the company. The existence of managerial ownership will further improve the performance of the company. it is because the ownership in the company, the manager will feel that the company is his, so he will try to run the company well. Therefore, the higher the managerial ownership, the better the company performance.

Ruan et al (2011) found that managerial ownership affect fir performance. The study of Li et al (2007) also found that managerial ownership has the positive effect on firm performance. Their findings indicated that the higher managerial ownership,

\section{Moderating Role of Tax Avoidance}

The test results by using moderated regression analysis shows that tax avoidance acts as a variable that moderates the influence between institutional ownership and managerial ownership on firm value. Negative beta values indicate that tax avoidance weakens the effect both between institutional ownership and managerial ownership on firm value. The occurrence of tax avoidance in companies will further weaken the effect of institutional ownership and managerial ownership on firm value. The test results indicate that the higher the institution ownership, it will be followed by the higher firm value. The occurrence of tax avoidance in companies will reduce the strong of the effect of institutional ownership in increasing the firm value.

Tax avoidance behavior by managers tends to have a decrease in firm value, caused by small profits as a result of tax avoidance. According to Armstrong et al. (2010) if a company avoids taxes with poor governance, it poses a risk of a conflict of interest, which will trigger an opportunity for managers to divert costs for their personal interests. It may also have an impact on the company's value. According to Aina (2016), the occurrence of tax avoidance will decrease firm value.

Hypothesis testing results that test the effect of managerial ownership on firm value indicates that managerial ownership affect firm value. A positive beta value indicates that the larger the managerial ownership, the higher the firm value. Testing on the role of tax avoidance as a variable that moderates the effect between managerial ownership on firm value shows significant $P$ value as well as beta which is negative. This indicates that the occurrence of tax avoidance weakens the influence between managerial ownership on firm value. The occurrence of tax avoidance at the company will reduce the role of managerial ownership in affecting firm value.

\section{CONCLUSIONS AND RECOMENDATIONS}

The objective of this study is to provide some empirical evidences of how institutional ownership and managerial ownership affect firm value, also want to investigate the moderating role of tax avoidance on the relationship between institutional ownership and managerial ownership on firm value. In this study it was proposed that institutional ownership and managerial ownership have a positive effecs on firm value. The result also showed that tax avoidance affects the relationship between institutional ownership and managerial ownership on firm value. This finding also suggests that interaction of tax avoidance weakened the influence of institutional ownership and managerial ownership on firm value.

The results of this study can help institutions such as the Indonesia Stock Exchange and also investors to know how the institutional ownership and managerial ownership affect the firm value. Besides, from the theoretical aspect, these findings provide a better understanding of the 


\section{agency theory more broadly.}

\section{Reference}

Allen, J.W dan Phillips, G.M, 2000. Corporate equity ownership, strategic alliances and product market relationships. Journal of Finance. Vol.55. hal.2791-2816.

Aina Qorri, 2016. Analysis of the effect of tax avoidance on corporate value with institutional ownership and transparency as moderating variables , Universitas Diponegoro.

Armstrong, Christopher,S., Wayne R.Guay., Yoseph P.Weber. 2010. The role of information and financial reporting in corporate governance and debt contracting. Journal of Accounting and Economics. 50:175-234.

Benson, Bradly.W and Wallace N. Davinson. (2008). Reexamining the Managerial Ownership Effect on Firm Value. Available on line at www.ssrn.com, diunduh 5 Maret 2013

Budianto, Wahyu dan Payamta.(2014). The influence of managerial ownership on firm value with dividend policy as moderating variables. ASSETS : Jurnal Akuntansi dan Pendidikan, Vol.3, No.1, April 2014

Chen, Zhang, Cheong K.C, Rajah Rasiah. (2016). Corporate Tax Avoidance and Performance: Evidence from China's Listed Companies. Institutions and Economies. Vo. 8 (3),pp.61-83

Cornett, Marcia Millon, Alan J. Marcus, \& Hassan Tehranian (2008). Corporate governance and pay-forperformance: The impact of earnings management. Journal of Financial economics, 87 ,357-373

Darmawan, I Gede Hendy dan I Made Sukartha. 2014. The effect of corporate governance, Leverage, Return on assets, and firm size on tax avoidance. E-Jurnal Akuntansi Universitas Udayana. 9 (1) : 143-161.

Dechow, P.M., Sloan, R.G. \& Sweeney, A.P. (1996). Causes and consequences to earnings manipulation: An analysis of firms subject to enforcement action by the SEC. Contemporary Accounting Research, 13,1-36.

Dewinta, Ida Ayu Rosa dan Putu Ery Setiawan. 2016. The inpact of firm size, firm age, profitability, leverage, and sales growth on Tax Avoidance. E-Jurnal Akuntansi Universitas Udayana, 14 (3): 1584-1613

Dyreng, S., M. Hanlon and E. Maydew. 2008. Long run corporate tax avoidance. The Accounting Review 83: 61-82.

Gideon, Boediono. 2005. Earnings quality: The study of the effect of corporate governance mechanism and the impact of earnings management using path analysis. Simposium Nasional Akuntansi (SNA) VIII Solo.

Gillan, S.L., Starks, L.T., (2003). Corporate governance, corporate ownership, and the role of institutional investors: a global perspective. Journal of Applied Finance , 13(2), 4-22

Gill, Amarjit. and Obradovich, John D. 2012. The impact of corporate governance and financial leverage on the value of American Firms. International Research Journal of Finance and Economics. 91

Gill, Amarjit. and Obradovich, John D. 2012. The impact of Ccrporate governance and financial leverage on the value of American Firms. International Research Journal of Finance and Economics. 91

Gozali, Imam. (2013). Application of multivariate analysis with IBM program, SPSS 21, update PLS regresi. Badan Penerbit Universitas Diponegoro, 7.

Hassan, Shehu Usman., Abubakar Abubakar. (2012). Corporate governance, earnings management, and Financial performance: A case of Nigerian manufacturing firms. American International Journal of Contemporary Research Vol. 2 No. 7, July.

Herawaty,Vinola. 2008. The role of corporate governance practices as a oderating variable of the effect of earnings management on firm value. Jurnal Akuntansi dan Keuangan. 10(2): 97-108

Hanlon, M. \& Heitzman, S. (2010). A review of tax research. Journal of Accounting and Economics , 50, $127-178$.

Hoque, Md Jahirul, Mohamad Zahid Hossain Bhuiyan, and Afzal. 2011. Tax avoidance crimes - A study on some corporate firms of Bangladesh

Jensen, Michael C. dan W.H. Meckling. (1976). Theory of the firm: Managerial behavior, agency cost and ownership structure. Journal of Financial Economics 3. hal. 305-360.

Kamardin, Hasnah. (2014). Managerial Ownership and Firm Performance: The Influence of Family Directors and Non-Family Directors .Ethics, Governance and Corporate Crime: Challenges and Consequences. 47-83

Kurniasih, Tommy dan Sari, Maria M. R. (2013). The effect of return on asset, leverage, corporate gorvenance, firm size and fiscal loss compensation on tax avoidance.Buletin Studi Ekonomi, Vol. 18: 58-66 
Li,Dong Hui., Fariborz.M., Pascal Nguyen Li., Wen Tan (2007). Managerial ownership and firm performance: Evidence from China's privatizations. Research in International Business and Finance. Vol.21(3): $396-413$

Mule, Robert Kisavi., Mohamed S.M., Onesmus,M. (2015). Corporate Size, Profitability and Market Value,:An Econometric Panel Analysis oo Listed Firms in Kenya. European Scientific Journal May 2015 edition vol.11, No.13 ISSN: 1857- 7881

Nuraina, Eva. (2012). The effect institutional ownership and firm size on debt policy and firm value (Study on manufactured company which is listed on Indonesian Stock Exchange). Jurnal Bisnis dan Ekonomi (JBE),9 (2) : 110-125

Maryam, Sitti. (2014). The analysis of the effect of firm size, growth, leverage, and profitability on firm value (Study on manufactured company which is listed on Indonesia Stock Exchange. Skripsi S1 Universitas

Mansor, N.A., Che-Ahmad., Ahmad-Zaluki, N.A., Osman, A. H. (2013). Corporate governance and earnings management: A study of the Malaysian family and non-family owned. International Conference on Economics and Business Research 2013 (ICEBR 2013).

Mule, Robert Kisavi., Mohamed S.M., Onesmus,M. (2015). Corporate Size, Profitability and Market Value,:An Econometric Panel Analysis oo Listed Firms in Kenya. European Scientific Journal May 2015 edition vol.11, No.13 ISSN: $1857-7881$

Prasetyorini, Bhekti Fitri. (2013). The effect of firm size, leverage, price earning ratio and Profitability on firm value. Jurnal Ilmu Manajemen, 1(1), h: 183-196.

Praditasari, Ni Koming Ayu., Putu Ery Setiawan. (2017). The effect of good corporate governace, firm size, leverage, and profitability on firm size. E Jurnal Akuntansi Universitas Udayana. 19(2):1229-1258

Pratama, I Gusti bagus Angga, I Gusti Bagus Wiksuana. (2016). The effect of firm size and leverage on firm value with profitability as a mediating variable. E- Jurnal Manajemen UNUD, 5 (2):1338-1367

Ratnawati, Vince., \& M. A. Abdul Hamid. (2015). The moderating effect of managerial ownership and institutional ownership on the relationship between control right and earnings management. Australian Academy of Accounting and Finance Review, 1 (1), 69-85

Ruan, Wenjuan; Tian, Gary; and Ma, Shiguang, Managerial Ownership, Capital Structure and Firm Value: Evidence from China's Civilian-run Firms, Australasian Accounting, Business and Finance Journal, 5(3), 2011, 73-92.

Saifudin., Derik Yuanda. (2016.) Determinant of return on asset, leverage, firm size, fiscall loss compensation and institutional ownership on tax avoidance (Empirical study on manufactured company which listed on Indonesian Stock Exchange from 2011 - 2014). . 6 (2); 131 -

Santa, Silvio Luis Leite, Amaury José Rezende. (2016). Corporate tax avoidance and firm value: from Brazil Florianopolis, v. 13, n. 30, p. 114-133

Scott D. Dyreng, Michelle Hanlon, and Edward L. Maydew (2008) Long-Run Corporate Tax Avoidance. The Accounting Review: January 2008, Vol. 83, No. 1, pp. 61-82.

Shahira, A. S. (2003). Does ownership structure affect firm value? Evidence from the Egyptian Stock Market. Unpublished Working Paper.

Slemrod, Joel., Shlomo Yitzhaki. (2002). Tax avoidance, evasion, and administration. Handook of Public Economics, 3; 1423-1470 from Elsevier

Sudianto, Bambang., Elen Puspitasari. (2010). Tobin's Q and Alman- Z Score as the indicator of firm performance measuremet. Kajian Akuntansi,2: 9-21

Swingly, Calvin., I MadeSukarta. (2015). The effect of executive characters, audit committee firm size, leverage, and sales growth on tax avoidance. E Jurnal Universitas Udayana, 10(1) ; 47-62

Wahyudi dan Perwestri, Hartini.P. (2006). The implication of ownership structures on firm value, financial decision as a intervening variable.SNA IX: Ikantan Akuntan Indonesia

Wida,Ni Putu., I Wayan Suartana. (2014). The effect of managerial ownership and institutional ownership on firm value. E-Jurnal Akuntansi Udayana 9(3): 575-590

Winata, Fenny. (2014). The effect of corporate governance on Tax Avoidance of manufactured company which is listing on Indonesian stock Exchange 2013. Tax \& Accounting Review,Vol 4 (No. I), hal 1-11.

Xudong Chen, Na Hu, Xue Wang, Xiaofei Tang, (2014) "Tax avoidance and firm value: evidence from China", Nankai Business Review International, Vol. 5 Issue: 1, pp.25-42, https://doi.org/10.1108/NBRI-10-2013-0037 